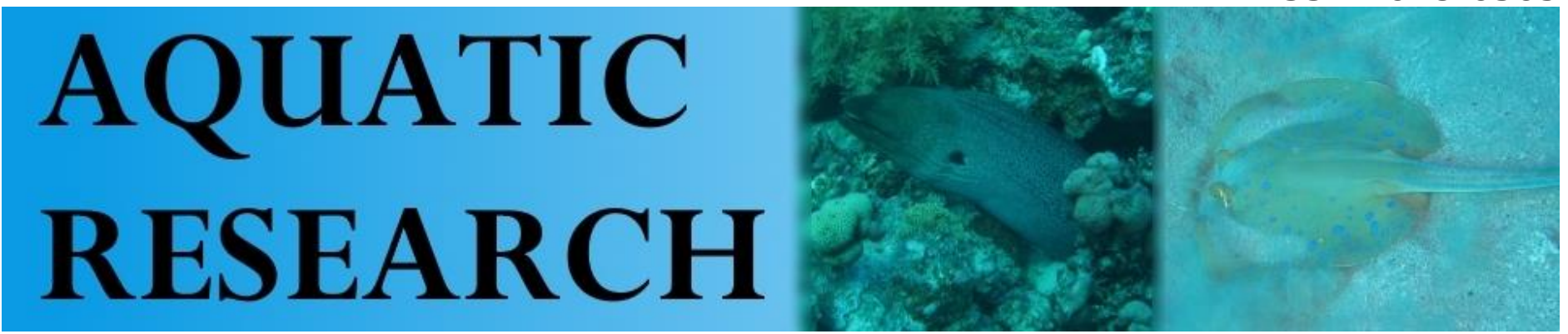

\title{
DETERMINATION OF SAGITTAL OTOLITH BIOMETRY AND BODY SIZE OF Serranus cabrilla (Linnaeus, 1758) DISTRIBUTED IN SOUTHERN AEGEAN SEA
}

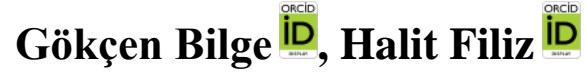

\section{Cite this article as:}

Bilge, G., Filiz, H. (2018). Determination of Sagittal Otolith Biometry and Body Size of Serranus cabrilla (Linnaeus, 1758) Distributed in Southern Aegean Sea. Aquatic Research, 1(2), 50-54. DOI: 10.3153/AR18006

Muğla Sitkı Koçman University, Faculty of Fisheries, 48000, Kötekli, Muğla, Turkey

Submitted: 23.01 .2017

Accepted: 20.02.2018

Published online: 24.02 .2018

Correspondence: Gökçen BíLGE

E-mail: gbilge@mu.edu.tr

@Copyright 2018 by ScientificWebJournals Available online at

http://aquatres.scientificwebjournals.com

\begin{abstract}
Fish otoliths are generally used to determine taxon, age and size of the teleost fishes and are useful tools for studies of prey-predator relationships, population dynamics and ichthyo-archaeology. In the present study, the equations for the relationships were calculated between fish length (TL), weight $(\mathrm{W})$ versus sagittal otolith length $(\mathrm{OL})$, height $(\mathrm{OH})$ and weight $(\mathrm{OW})$ in comber (Serranus cabrilla, Linnaeus, 1758) specimens ( $\mathrm{N}=310,95-225 \mathrm{~mm}$ in $\mathrm{TL}$ and 7.54-111.27 g) captured via bottom trawl vessels from off the Güllük Bay (Southern Aegean Sea) between January and December 2013. Since there has been no statistical differences between left and right otoliths ( $p>0.05)$, left otoliths were used for calculations. Regression formulas were calculated as follows: $\mathrm{TL}=28.75 * \mathrm{OL}-22.31, \quad \mathrm{TL}=64.36 * \mathrm{OH}-6.808, \quad \mathrm{TL}=2380 * \mathrm{OW}^{0.640}, \quad \mathrm{~W}=0.056 * \mathrm{OL}^{3.618}$, $\mathrm{W}=2.029 * \mathrm{OH}^{3.254}, \mathrm{~W}=5168 * \mathrm{OW}-28.33, \mathrm{OH}=0.414 * \mathrm{OL}-0.054, \mathrm{OW}=0.0000053 * \mathrm{OL}^{1.542}$, and $\mathrm{OW}=0.003 * \mathrm{OH}^{1.382}$. The aim of this study is to fill in the missing data concerning otolith and fish size relationships of the species in the southern Aegean Sea, thereby providing researchers studying food habits of top predators to determine the size and weight of prey fish from length or weight of recovered otoliths.
\end{abstract}

Keywords: Comber, Serranidae, Sagittae, Otolith size 


\section{Introduction}

Otoliths have distinctive shape which is highly species specific, but varies widely among species (Maisey, 1987). Thus, several identification guides and keys has been published by Smale et al (1995) for south African Fishes, Harkönen (1986) for northeast Atlantic Sea, Morrow (1976) for Bering Sea, Campana (2004) for northwest Atlantic Ocean, Tuset et al. (2008) for the western Mediterranean, north and central eastern Atlantic, and Nolf (1985) for fossil fishes. The prey specimens are partially or totally digested and the hard remains in stomachs, intestines, faeces and scats (of piscivorous fishes, marine mammals, sea birds) are only diagnostic features that can be considered; among those hard remains, otoliths are quite resistant to digestion and they are important tools for prey classification (Al-Mamry et al., 2010). The comber Serranus cabrilla (Linnaeus, 1758 ) is a demersal fish species found at depth ranges between 5-500 m on the continental shelf and upper slope over rocks, Posidonia beds, sand and mud bottoms (Tortonese, 1986). It distributes in temperate and tropical regions, Eastern Atlantic: English Channel southward round the Cape of Good Hope to Natal, South Africa (Heemstra\&Randall, 1986), including Azores, Madeira and the Canary Islands (Tortonese, 1986). Also in the Mediterranean and western Black Sea. This study represents the first information on the otolith-fish size relations of Serranus cabrilla, collected from the Güllük Bay (the southern Aegean Sea).

\section{Materials and Methods}

In the present study, the relationship equations were calculated between fish length (TL), weight (W) versus sagittal otolith length $(\mathrm{OL})$, height $(\mathrm{OH})$ and weight $(\mathrm{OW})$ in comber (Serranus cabrilla, Linnaeus, 1758) specimens captured via bottom trawl vessels from the Güllük Bay (Southern Aegean Sea) between January and December 2013.

Total lengths (TL) were measured to the nearest millimeter. Fish weight $(\mathrm{W})$ were determined to the nearest $0.01 \mathrm{~g}$ on a digital balance. Sagittae were $(\mathrm{N}=310)$ removed through a cut in the cranium to expose them then cleaned and stored dry in glass vials and the left and right otolith were considered separately. Each sagitta was placed with the sulcus acusticus oriented through the observer and otolith length (OL) and otolith height $(\mathrm{OH})$ was determined using eyepiece micrometer under stereo zoom microscobe (Olympus SZX-16) and defined as the longest dimension between the rostrum and postrostrum axis (nomenclature of Smale et al., 1995 and Tuset et al., 2008) through the focus of the otolith (Al-Mamry et al., 2010) (Figure 1). Individual sagittal otolith weight (OW - in $0.1 \mathrm{mg}$ ) was determined using an electronic balance. Firstly, the paired t-test was used to check any differences between left and right otolith pairs. When significant differences $(\mathrm{P}<0.05)$ were not found, the $H_{0}$ hypothesis $\left(b_{\text {right }}=b_{\text {left }}\right)$ was accepted and a single regression was used for each parameter (OL, OH and OW). Linear, $Y$ $=a x+b$ and non-linear, $Y=a x^{b}$ regression equations were fitted to determine which equations (OW-W, OL-OW, TL$\mathrm{OH}, \mathrm{OH}-\mathrm{W}, \mathrm{OW}-\mathrm{OH}, \mathrm{OL}-\mathrm{W}, \mathrm{OL}-\mathrm{TL}, \mathrm{OH}-\mathrm{OL}$, and OWTL) are best describing various relationships between otolith and fish size (Tarkan et al., 2007).

\section{Results and Discussion}

The sagittal otoliths of $310 \mathrm{~S}$. cabrilla specimens were examined. Table 1 shows the descriptive statistics regarding length and weight of the species and its sagittal otoliths (with otolith width): the average total length $( \pm$ S.D) was $14.589( \pm 2.909) \mathrm{mm}(95-225 \mathrm{~mm})$, and the length of otoliths ranged from 3.8 to $8.3 \mathrm{~mm}$, height from 1.5 to $3.6 \mathrm{~mm}$, and weight from 0.0077 to $0.0251 \mathrm{~g}$.

Relations between fish and otolith measurements were given in Table 2, and the relationships between otolith morphometric parameters and fish sizes of $S$. cabrilla were given in Figure 2. No significant differences (t-test for paired comparisons, $\mathrm{P}>0.05$ ) were found between left and right otolith length and weight data. Therefore, the left sagittae measurements were used for the calculation of equations. Calculated regressions were displayed a high coefficient of determination ranging between 0.793 - 0.938. A linear regression model was used to determine the relationship between the fish length and otolith sizes, but an exponential regression model was used to describe the relationships between lengths and weights of otolith and fish for the species.

$S$. cabrilla is a discard or by-catch species by trawl landings in Turkey. Despite it has not any commercial value, ecological importance come from to be found in predators' diet. Otoliths are used extensively in stomach content analysis because they are one of the last species-specific features to be digested (Smale et al., 1995). This "powerful" taxonomic feature of earstones, allowed fish species identification. Even though there is some reference identification guides and keys for western Mediterranean, Atlantic Ocean and adjacent waters, this case is very limited, just for some species specific papers, for eastern Mediterranean. At this point, studying the marine predators' feeding habits is to fill the gap of information on the fish otolith morphology and on the estimation of specific equations, which is useful to calculate the size and mass of preys (Battagllia et al., 2010). 
Table 1. Descriptive statistics of length and weight data of specimens and their otoliths obtained from the Southern Aegean Sea.

\begin{tabular}{lcc}
\hline & Range & Average $( \pm$ S.D.) \\
\hline TL $(\mathbf{m m})$ & $95-225$ & $14.589( \pm 2.909)$ \\
W $(\mathbf{g})$ & $7.54-111.27$ & $38.569( \pm 22.34)$ \\
OL $(\mathbf{m m})$ & $3.8-8.3$ & $5.849( \pm 0.980)$ \\
OH $(\mathbf{m m})$ & $1.5-3.6$ & $2.37( \pm 0.430)$ \\
OW $(\mathbf{g})$ & $0.0077-0.0251$ & $0.0129( \pm 0.0039)$ \\
\hline
\end{tabular}

Total length (TL), Fish weight (W), Otolith length (OL), Otolith weight (OW) and Otolith height $(\mathrm{OH})$, Standart deviation (S.D.)

Table 2. Intercept values (a), regression slope (b) and coefficients of determination $\left(\mathrm{r}^{2}\right)$ for linear (L) and exponential (E) relationships between otolith morphometric parameters, fish length and weight of S. cabrilla.

\begin{tabular}{|c|c|c|c|c|c|}
\hline & Relationship & Regression & $\mathbf{a}$ & b & $\mathbf{r}^{2}$ \\
\hline \multirow{3}{*}{ 昰 } & TL vs. OL & $\overline{\mathrm{L}}$ & 28.75 & -22.31 & 0.938 \\
\hline & TL vs. OH & $\mathrm{L}$ & 64.36 & -6.808 & 0.908 \\
\hline & TL vs. OW & $\mathrm{E}$ & 2380 & 0.640 & 0.838 \\
\hline \multirow{3}{*}{$\frac{\vec{z}}{200}$} & W vs. OL & $\mathrm{E}$ & 0.056 & 3.618 & 0.917 \\
\hline & W vs. OH & $\mathrm{E}$ & 2.029 & 3.254 & 0.887 \\
\hline & W vs. OW & $\mathrm{L}$ & 5168 & -28.33 & 0.822 \\
\hline \multirow{3}{*}{ 竞 } & OW vs. OL & $\mathrm{E}$ & 0.000053 & 1.542 & 0.825 \\
\hline & OH vs. OL & $\mathrm{L}$ & 0.414 & -0.054 & 0.891 \\
\hline & OW vs. OH & $\mathrm{E}$ & 0.003 & 1.382 & 0.793 \\
\hline
\end{tabular}

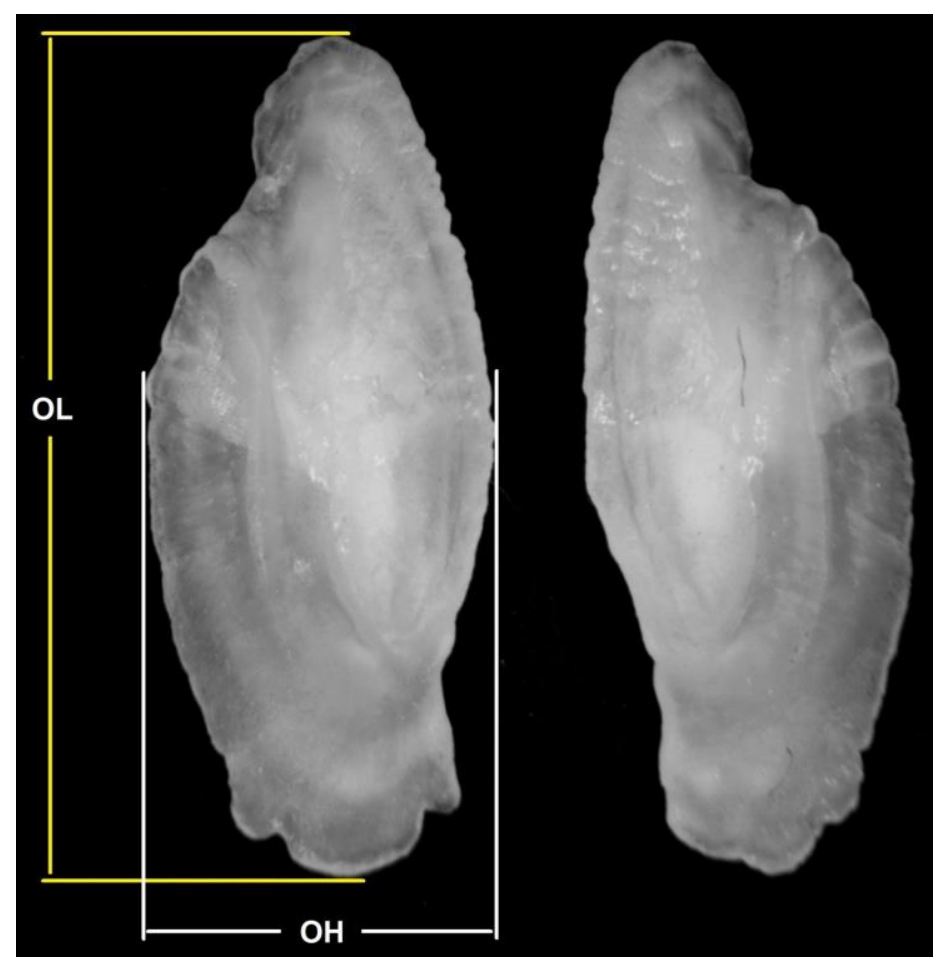

Figure 1. Sagittal otolith of the comber, Serranus cabrilla, sampled from the southern Aegean Sea in 2013 (Total length of the fish $=225 \mathrm{~mm}$, otolith length $=8.3 \mathrm{~mm}$; $\mathrm{OL}=$ otolith length, $\mathrm{OH}=$ otolith height $)$. 

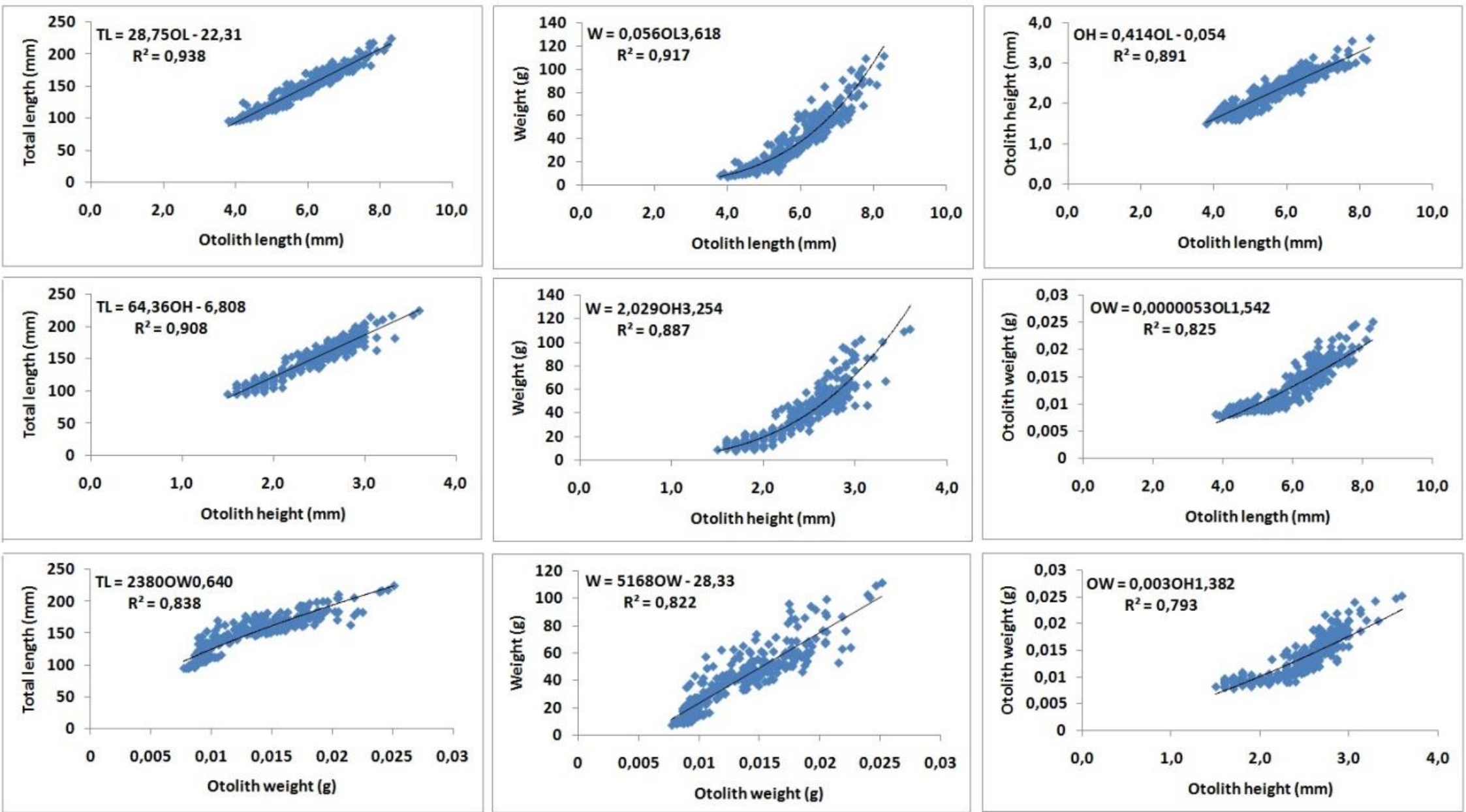

Figure 2. Relationships between otolith morphometric parameters and fish sizes of $S$. cabrilla. 
Tuset et al. (2008) reported a \% ratio relationships between the length of $S$. cabrilla $(70,177$ and $255 \mathrm{~mm}$ TL, $\mathrm{n}=3)$ and Sagitta sizes as $\mathrm{OL} / \mathrm{TL}=3.4-4.2$ and $\mathrm{OH} / \mathrm{OL}=39.9-47.1$; in the present study $(95-225 \mathrm{~mm} \mathrm{TL}, \mathrm{n}=310)$ these ratios were calculated as $\mathrm{OL} / \mathrm{TL}=3.3-4.5$ and $\mathrm{OH} / \mathrm{OL}=33.9-48.1$.

\section{Conclusion}

The growth of individuals belonging to the same species may show some differentiations for different areas and stocks (Campana and Casselman, 1993). Therefore, a species had been studied its distribution area, separately, on this object. To meet this need, actually, small part of this lack, this study is providing $\mathrm{OW}-\mathrm{W}, \mathrm{OL}-\mathrm{OW}, \mathrm{TL}-\mathrm{OH}, \mathrm{OH}-\mathrm{W}$, OW-OH, OL-W, OL-TL, OH-OL, and OW-TL relationships for the species.

\section{References}

Al-Mamry, J., Jawad, L., Al-Busaidi, H., Al-Habsi, S., AlRasbi, S. (2010). Relationships between fish size and otolith size and weight in the bathypelagic species, Beryx splendens Lowe, 1834 collected from the Arabian Sea coasts of Oman. Quaderni del Museo di Storia Natturale di Livorno, 23, 79-84.

Battaglia, P., Malara, D., Romeo, T., Andaloro, F. (2010). Relationships between otolith size and fish size in some mesopelagic and bathypelagic species from the Mediterranean Sea (Strait of Messina, Italy). Scientia Marina, 74(3), 605-612.

Campana, S.E. (2004). Photographic atlas of fish otoliths of the northwest Atlantic Ocean. Canadian Special Publication of Fisheries and Aquatic Sciences 133. NRC Research Press. Ottawa, ON, Canada, 284 p, ISBN 9780660191089

Campana, S.E., Casselman, J.M. (1993). Stock discrimination using otolith shape analysis. Canadian Journal of Fisheries and Aquatic Sciences, 50(5), 1062-1083.

Härkönen, T. (1986). Guide to the otoliths of the bony fishes of the northeast Atlantic. Danbiu ApS. Biological Consultants, Hellerup, Denmark, 256 p, ISBN 8798229028
Heemstra, P.C., Randall, J.E. (1986). Serranidae. p. 509537. In M.M. Smith and P.C. Heemstra (eds.) Smiths' sea fishes. Springer-Verlag, Berlin. ISBN 9783642828584

Maisey, J.G. (1987). Notes on the structure and phylogeny of vertebrate otoliths. Copeia, 2, 495-499.

Morrow, J.E. (1976). Preliminary keys to otoliths of some adult fishes of the Gulf of Alaska, Bering Sea and Beaufort Sea. NOAA Technical Reports NMFS Circular 420.

Nolf, D. (1985). Otolithi piscium. In: Schultze H.P (ed.) Handbook of Paleoichthyology, Vol. 10, Gustav Fischer Verlag, Stuttgart, New York. Book series: Handbook of paleoichthyology. Vol. 10. Gustav Fischer Verlag, Stutgart, New York, 145 p, ISBN 9783899370393

Smale, M.J., Watson, G., Hetch, T. (1995). Otolith atlas of southern African marine fishes. Ichthyological Monographs No. 1. J.L.B. Smith Institute of Ichthyology, Rhodes University, Grahamstown, South Africa, 418 p, ISBN 9780868102948

Tarkan, A.N., Bilge, G., Gaygusuz, Ö., Tarkan, A.S., Gürsoy, C. \& Acipınar, H. (2007). On the use of otoliths of a Ponto-Caspian gobiid Proterorhinus marmoratus (Pallas, 1814) from lake İznik (Turkey) in prey-predator studies. International Journal of Natural and Engineering Sciences, 1(3), 29-33.

Tortonese, E. (1986). Serranidae. In P.J.P. Whitehead, M.L. Bauchot, J.-C. Hureau, J. Nielsen \& E. Tortonese (Eds.) Fishes of the north-eastern Atlantic and the Mediterranean (p. 780-792). UNESCO, Paris. vol. 2, ISBN 9789230023089

Tuset, V.M., Lombarte, A. \& Assis, C.A. (2008). Otolith atlas for the western Mediterranean, north and central eastern Atlantic. Scientia Marina, 72(S1), 7-198. 